NOTES ON NATURAL HISTORY

\title{
Xylanase Production from Fungi Extracted from Two Distinct types of Crop Producing Soil of Chhattisgarh, India
}

\section{Akrati Shrivastava*, Devyani Sharma, Vishwaprakash Roy, Ashis Sarkar \\ School of Biological and Chemical Sciences, MATS University, Raipur, Chhattisgarh, India}

\section{Introduction:}

Xylanase is hydrolytic enzymes capable of hydrolyzing polysaccharide -1, 4-xylan in hemicelluloses a component of plant cell wall (Dhiman et al., 2008). Xylans are the second most abundant natural polysaccharide (Collins et al., 2005). It is a complex heteropolysaccharide having a highly branched chain of 1, 4-linked xylanopyranosyl residues (Bastawade, 1992). Xylanases (EC 3.2.1.8) catalyze the hydrolysis of xylan, the major constituent of hemicelluloses found in plant cell wall. (Kulkarni et al., 1999). Xylanases are produced by a diverse group of organisms such as bacteria, algae, fungi, protozoa, gastropods and arthropods (Collins et al., 2005). Concentration for xylanolytic enzymes has increased due to its potential use in several industrial processes such as biopulping and bleaching; bioconversion of lignocellulose; food processing, including clarification of beer, wine, and juice; increasing digestibility of animal feedstock; and bread making (Bastawade, 1992; Vikari et al., 1994; Uffen 1997). An attempt has been taken to extarct Xylanase from the soil collected from two diverse types of crop producing land i.e., sugarcane and rice

Species extraction and its enzymatic activity: Soil samples collected during the month of August from targeted fields existing around Raipur were stored at $4^{\circ} \mathrm{C}$. Fungi were isolated from soil samples by serial dilution method and pure culture were stored in Potato Dextrose Agar Media (Waksman, 1927; Jasuja et al., 2013). Fungi species extracted were identified under the compound microscope and by lactophenol cotton blue staining following morphological studies Jones, (1965).

For fungi an initial screening was done in PDA xylan medium by plate assay method using congored solution. Zone of hydrolysis was measured in centimeters $(\mathrm{cm})$ (Ramanjaneyulu, et al., 2015). When the zone of hydrolysis reached more than $5 \mathrm{~cm}$ were selected and further screened in submerged state fermentation $(\mathrm{SmF})$ for the production of xylanase. Erlenmeyer flasks ( $250 \mathrm{ml}$ ) containing $50 \mathrm{ml}$ of liquid MSM medium with $0.5 \mathrm{mg}$ of wheat bran as carbon source was inoculated with 1 fungal disc of $8 \mathrm{~mm}$ size and
Study Area: Raipur, Chhattisgarh, India... Coordinated: $21^{\circ} 17^{\prime} 27.9^{\prime \prime} \mathrm{N}$; $81^{\circ} 43^{\prime} 40.7^{\prime \prime} \mathrm{E}$

Key words: Enzymatic activity, Sugarcane, Rice, Carbon source, Nitrogen source

incubated at 28 o $\mathrm{C}$ for 7 days.1.5ml aliquot were withdrawn from each flask each day and filtered through Whatman No.1 filter paper. Filtrate was collected and used as enzyme source for the assay of xylanase activity.

For the proper reaction mixture, we followed the process forwarded by Miller, (1959) where using xylose as standard, the amount of xylose liberated was quantified.

One unit of xylanase activity $(\mathrm{U})$ can be defined as the amount of enzyme that liberates $1 \mu$ molar of reducing sugar - xylose per minute under standard assay conditions.

\section{Method optimization for betteryield:}

Variation of incubation time: wheat bran, sugarcane baggase, spilt green gram (mung daal bran) and rice bran were incubated for 24 hours, 48 hours, 72 hours, 96 hours, 120 hours and 144 hours.

Impact of various substrate: wheat bran, sugarcane baggase, mung daal and rice bran were used separately to get the maximum xylanase activity. The highest production was observed in wheat bran $(0.065 \mathrm{mg} / \mathrm{ml})$.

Impact of various temperature: to get the optimum range of temperature, test were done on $25^{\circ} \mathrm{C}, 30^{\circ} \mathrm{C}, 35^{\circ} \mathrm{C}$, $40^{\circ} \mathrm{C}, 45^{\circ} \mathrm{C}$ and $30^{\circ} \mathrm{C}$ was most eff icient $(0.048 \mathrm{mg} / \mathrm{ml})$.

Impact of various $\mathbf{p H}$ range: to get the best-suited $\mathrm{pH}$ medium, tests were done with $\mathrm{pH}$ ranging from 5 to 9 and it was best in $5(0.046 \mathrm{mg} / \mathrm{ml})$.

Impact of various Carbon source: to established bestsuited carbon source for maximum yield of xylanase, we used xylose, dextrose, lactose, maltose, starch (Tallapragada \& Venkatesh, 2011) and dextrose was the most efficient at $5 \%$ concentration $(0.056 \mathrm{mg} / \mathrm{ml})$.

Impact of various Nitrogen source: Ammonium nitrate, sodium nitrate, peptone, yeast extract (Tallapragada \& Venkatesh, 2011) were used to standarized the maximum xylanase activity and the peptone yield maximum output (0.051 mg/ml).

Impact of Shaking / Non- Shaking during incubation: among Shaking and Non Shaking incubation employed at $28^{\circ} \mathrm{C}$ for 7 days, the shaking conditions for $96 \mathrm{hr}$ gave the most satisfactorily result.।

We identified ten isolates belonging to four genera

*Corresponding Author: akrati_biotech@yahoo.com 
NOTES ON NATURAL HISTORY

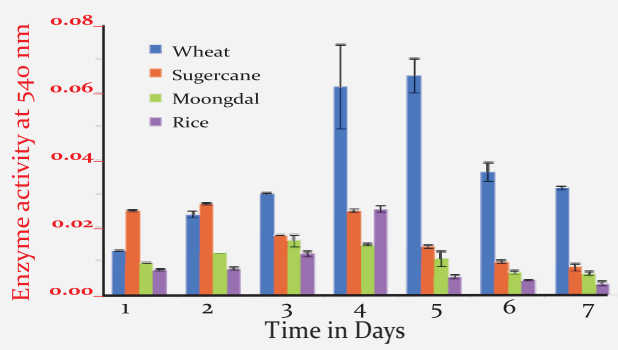

Figure-1: Impact of Timeand Substrate on Enzyme Activity

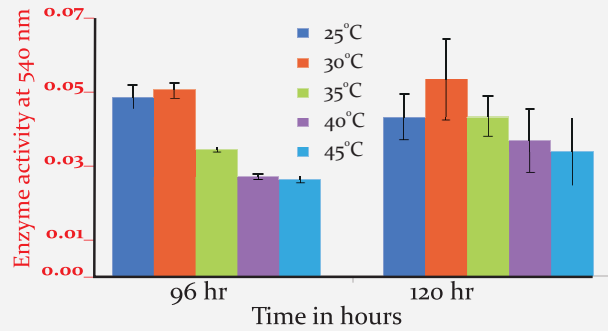

Figure-2: Impact of Temperature on Enzyme Activity

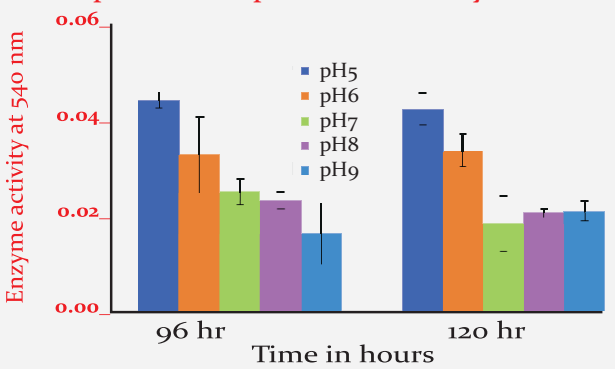

Figure-3: Impact of different $\mathrm{pH}$ on Enzyme Activity

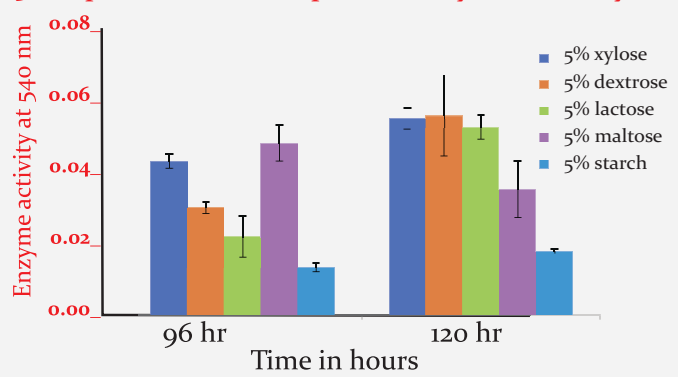

Figure-4: Impact of different Carbon sources on Enzyme Activity

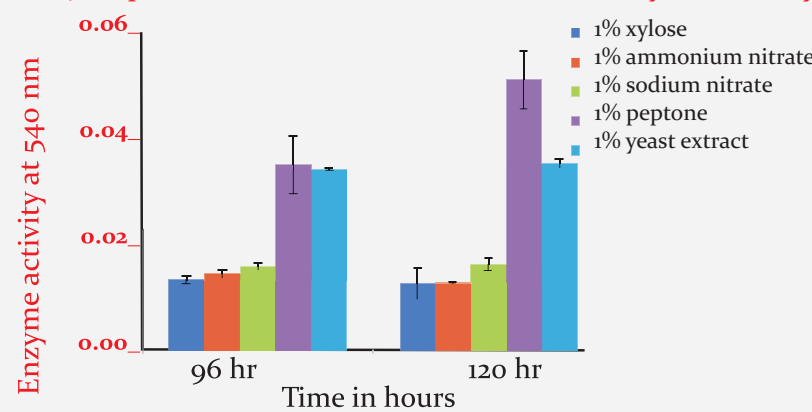

Figure-5: Impact of Nitrogen Sources on Enzyme Activity

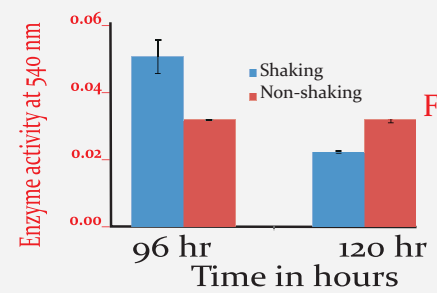

Figure-6: Impact of Shaking \& Non-Shaking Condition on Enzyme Activity namely Aspergillus, Trichoderma, Fusarium and Penicillium from the targetted soil samples. Aspergillus niger was found to be the most potent one. In primary screening two isolates viz. Aspergillus niger, Penicillium exhibited more than $5 \mathrm{~cm}$ zone of hydrolysis $(5.8 \mathrm{~cm}$ and 5.3 cm respectively).

Gupta et al. (2009) found 16 fungal isolates with zone of hydrolysis ranging between 3.4 to $4.8 \mathrm{~cm}$. Penicillium oxalicum was opted for producing xylanase on plate assay method by Muthezhilan et al. (2007). Tallapragada \& Venkatesh, (2011) selected Aspergillus niger as xylanase producer.

Conclusively the baseline of our study could be the beneficiary in Xylanase production which plays an important role in increasing the nutritional value of feed ingredients, reduces the cost of feed as well as maintains or improves animal performance. Further, fibres of feed ingredients hamper digestibility of poultry, which can be overcome by the use of xylanase.

\section{References:}

Bastawade, K.B. (1992): Xylan structure, microbial Xylanase, and their mode of action Wor.J. Microbiol. Biotechnol., 23(1):4-10.

Collins, T., Gerday, C. \& Feller G. (2005): Xylanases, xylanases families and extremophilic xylanases. FEMS Microbiol. Rev., 29(1):3-23.

Dhiman, S.S., Sharma, J. \& Battan, B. (2008): Industrial Applications and future prospects of Microbial Xylanases: A Review. BioResources, 3(4):1377-1402.

Gupta, V.K., Gaur, R., Gautam, N., Kumar, P. Yadav, I.J. \& Darmwal, N.S. (2009): Optimization of xylanase production from Fusarium solani F7. Am. J. Food Technol., 4(1):20-29.

Jones, K.L. (1965): Thermophilic Fungi, An Account of Their Biology, Activities, and Classification. Cooney \& Emerson (ed.) ," The Quarterly Review of Biology •40,(3). 292 p.

Jasuja, N.D., Saxena, R., Chandra, S. \& Joshi, S. C. (2013). Isolation and identification of microorganism from polyhouse agriculture soil of Rajasthan. Af. J. Microbiol., 7(41):4886-4891.

Kulkarni, N., Shendye, R.A. \& Rao, M. (1999): Molecular and biotechnological aspects of xylanases. FEMS Microbiol. Rev., 23:411-456.

Miller, G.L. (1959): Use of Dinitrosalicylic Acid Reagent for Determination of Reducing Sugar. Anal. Chem., 31(3): 426-428.

Ramanjaneyulu, G., Reddy, P.K., Kumar, K.D. \& Reddy, B.R. (2015): Isolation and Screening of Xylanase Producing Fungi from Forest Soils. Int. J. Curr. Microbiol. Appl. Sci., 4(9):586-591.

Tallapragada, P. \& Venkatesh, K. (2011): Isolation, identification and optimization of xylanase enzyme produced by Aspergillus niger under submerged fermentation._J. Microbiol. Biotechnol. Res., 1(4):137-147.

Uffen R.L. (1997). Xylan degradation: a glimpse at microbial diversity. L. Ind. Microbiol. Biotechnol., 19(1):1-6.

Viikari, L., Kantelinen, A., Buchert, J. \& Puls J. (1994): Enzymatic accessibility of xylans in lignocellulosic materials. Appl. Microbiol. Biotechnol., 41(1):124-129.

Waksman, S.A. (1927): Principles of soil microbiology. Pub. by: Batimore; William \& Wilkins co. 974p. 